\title{
Cleft lip and palate review: Epidemiology, risk factors, quality of life, and importance of classifications
}

\author{
Laureen Supit', Theddeus OH Prasetyono²
}

\begin{abstract}
Abstrak
Bibir sumbing dengan atau tanpa sumbing langit-langit adalah cacat bawaan kraniofasial yang paling banyak ditemukan. Penyebabnya kompleks dan melibatkan banyak faktor genetik dan lingkungan. Cacat bawaan ini dapat menyebabkan banyak morbiditas, serta beban ekonomi yang berat; karena pasien sumbing membutuhkan intervensi medis setidaknya selama 18 tahun pertama yang mencakup beberapa aspek kehidupan pasien. Derajat dan kompleksitas sumbing sangat bervariasi, yang nantinya akan menentukan tatalaksana dan hasil akhir rekonstruksi untuk tiap individu. Identifikasi dan klasifikasi sangat berperan dalam penilaian awal kasus sumbing yang masing-masing unik, selanjutnya menjadi panduan untuk pemilihan metode yang tepat untuk mengoreksi defek. Beberapa klasifkasi yang ada dapat mengukur derajat keberhasilan rekonstruksi setelah operasi. Upaya yang telah dilakukan dan tantangan untuk dapat memformulasikan suatu klasifikasi yang ideal dan mencakup semua jenis sumbing ditelaah dalam tulisan ini. (Med J Indones 2008; 17: 226-39)
\end{abstract}

\begin{abstract}
Cleft lip with or without cleft palate is the most occurring craniofacial anomaly in human, resulting from a complex etiology involving multiple genetic and environmental factors. The defect carries lifelong morbidity and economic burden. Children with clefts will require continuous medical interventions for at least the first 18 years of life, affecting many aspects of their lives. The extent and complexity of clefts vary infinitely, later determining individual management and outcome. Identification and classification play significant roles in initial assessment of these unique cleft cases, which affect options for following correctional attempts. Some classifications even allow measurement of progress after anatomical repositioning, and success rate after surgical repairs. The challenge of developing one such widely inclusive classification is discussed. (Med J Indones 2008; 17: 226-39)
\end{abstract}

Keywords: Cleft lip, cleft palate, congenital anomaly, cleft classifications

Clefts are formed when the right and left side of lip or palate do not fuse together completely during fetal growth, causing a gap in between. The mouth consists of structures which together perform numerous motoric and sensoric functions such as vocal articulation, chewing, tasting, among others. Clefts of the lip with or without cleft palate (CL/CP) impose aesthetic, structural and functional defects to babies born with them including abnormal facial appearance and expression, difficulty in feeding and its impact on delayed growth,

1 Faculty of Medicine University of Indonesia, Jakarta, Indonesia

2 Division of Plastic Surgery, Department of Surgery, Faculty of Medicine University of Indonesia, Dr. Cipto Mangunkusumo Hospital, Jakarta, Indonesia disturbed speech and hearing development, irregularity and displacement of teeth, including other economical and psychological burden.

\section{PREVALENCE}

$\mathrm{CL} / \mathrm{CP}$ is one of the most occurring human congenital anomalies, with differences in respect to parental ethnicity and geographic origin, gender of the fetus, and socioeconomic status of the family. It approximately affects one baby of every 700 to 1000 born. ${ }^{1}$ In general, clefts occur more commonly in Asians and American Indian ( 1 in 500 births), ${ }^{2}$ less frequently in Caucasians (1 in 1000 births $)^{2}$ and even more uncommonly in African Americans (1 in 2000 births). ${ }^{1}$ In 2001 nationwide epidemiological count in the United States, CL/CP is 
the second most occurring birth defects after Down syndrome at 10.48 cases per 10,000 birth. $^{3}$ Several studies found that incidence of $\mathrm{CL} / \mathrm{CP}$ among Chinese and Philippine infants born in the United States is lower than those born in their native country. ${ }^{2}$ Infants born to family with lower socioeconomic status are shown to have an increased risk for $\mathrm{CL} / \mathrm{CP}$, which might explain the above geographical incidence difference.

In 1973, it was discovered by Anthony Pelly of Australia that every hour in Indonesia, six babies with cleft are born. It means in two and a half days Indonesia gives birth to cleft babies equal to the number that Australia labors in a year ( 1 in 600 births). ${ }^{4}$ Cleft deformities occurs in form of both cleft lip and cleft palate together (CLP) in $45 \%$ of cases, followed by cleft palate alone (CP) $35 \%$, and cleft lip alone (CL) 20\%.' In Indonesia the ratio is much different, with CLP cases being the most rare at $2 \%$ followed by $13 \% \mathrm{CP}$ and $85 \%$ CL. ${ }^{4}$ Data from our office, Indonesia Association of Plastic Surgeons (PERAPI) more-or-less supports this figure. In the period of 1997 to $2008,4.758$ patients with cleft lips and 1.235 with cleft palate from many regions of Indonesia were operated by surgeons of PERAPI. Gender differences ratio are dependent upon the type of clefts. CLP and CL are more common in males, CP is more frequent in females. ${ }^{1}$

Genetic influence of CL/CP does not follow a simple Mendelian formula, but siblings of cleft patients are at greater risk. Curtis et al. calculated that the risk of recurrence of $\mathrm{CL} / \mathrm{CP}$ in subsequently born children is $4 \%$ if one child has it, $4 \%$ if one parent has it, $17 \%$ if one parent and one child have it, and $9 \%$ if two children have it. ${ }^{5}$ Approximately $10 \%$ of patients with a cleft deformity will also have other anomalies at birth. ${ }^{6}$ This is known as the syndromic cleft, and there are more than 300 known syndromes associated with CL and/or CP.

The estimated accumulated economic cost for management of a child with $\mathrm{CL} / \mathrm{CP}$ is about USD 101,000 per child, including a range of surgical to orthodontic treatment. ${ }^{6}$ Data from our office, in Indonesia the estimated cost for one surgical procedure for the repair or $\mathrm{CL}$ or $\mathrm{CP}$ only (including inpatient care and related postsurgical medications) is approximately IDR $1,770,000$ ( \pm USD 190). But this data on surgical cost is based only on full charity works, for a single lip and palate reconstruction per se.

\section{ETIOLOGY AND RISK FACTORS}

An abnormality in the genetic make-up of a developing fetus is $1 \%$ of the time influenced by teratogens, $5.5 \%$ by maternal factors, $18 \%$ by chromosomal abnormalities, $22 \%$ by single gene anomaly, and $60 \%$ of the time by multifactorial effects. The first comprehensive study to suggest that there was a genetic cause CL/CP was by Fogh-Andersen in 1942. In 1943 Warkany et al. showed that there were also certain environmental deficits and exposures involved in the occurrence of CL/CP. Thereafter, causes of $\mathrm{CL} / \mathrm{CP}$ are said to be multifactorial. Transforming growth factor alpha (TGFA), transforming growth factor beta 3 (TGFB3), MSX1 and AP2 are genes that have been identified as having a major role in the development of CL/CP.

Environmental factors can be divided into four categories: womb environment, external environment, nutrition and drugs. The several known teratogens that increase the risk of $\mathrm{CL} / \mathrm{CP}$ include phenytoin and valproic acid, dioxin (pesticide), thalidomide, retinoic acid, maternal alcohol use, and maternal cigarette smoking.? Lack of maternal nutrition, specifically folic acid, was noted to alter embryonic facial growth resulting in increased rates of clefting.

\section{DISABILITY AND LIMITATIONS}

$\mathrm{CL} / \mathrm{CP}$ affects the children in many ways, most noticeably the tendency to have an abnormal midfacial appearance and growth. An intact lip and palate are fundamental for feeding as well as for speech and language development. CL may cause problem in creating a seal around the nipple for suction during breast feeding. CP prevents babies from creating the negative pressure necessary to feed, limits the normal use of the tongue to compress the nipple, and may also lead to breathing problems during feeding. Problems with feeding during infancy lead to a negative impact on overall growth. Studies found that Danish boys aged 6 to 20 years with clefts have delayed skeletal maturity compared to a control group over the whole period. Other findings include weight gain rate per week in neonates with clefts was proven to be lower than without. Clefting was associated with significant growth faltering in early infancy. Clefting has also been associated with increased risks of failure to thrive and risk of severe dehydration. ${ }^{8}$ 
In regard to the development of higher cortical function, toddlers with cleft had significantly lower scores on tests of cognition, comprehension and expressive language abilities as well as lower developmental performance in fine motor and gross motor skills. ${ }^{9}$ The posterior end of the soft palate is also known as the velopharyngeal flap. During speech production this flap will move backward, come in contact with the pharyngeal wall and separate the nasopharynx with oropharynx. This closure is essential because phonation involves the generation of a column of air pressure passing from the subglottis into the upper airway. Insufficiency of the velopharyngeal flap allows air to escape through the nose during the generation of consonants leading to inappropriate nasal resonance during speech. An anatomical deficiency in the soft palate which generally also affects the superior constrictor muscle result in the inability to achieve sufficient velopharyngeal closure.

Subjects with clefts of the palate have demonstrated a high incidence of hearing disability. Part of the explanation is that most $\mathrm{CP}$ individuals have inadequate Eustachian tube ventilation of the middle ear due to an abnormal insertion of the levator palatini and tensor veli palatini muscles into the palate, muscles who are responsible for the normal opening of Eustachian tube. This condition may result in a retracted tympanic membrane with multiple air/fluid levels and is responsible for the very high rates of otitis media with effusion among patients with cleft palate. ${ }^{10}$ The prevalence of this problem was shown to be affecting almost all CP patients whereas latter studies reported slightly lower rates of $97 \%$ and $92 \%$. This frequent effusive otitis media will pose a problem in the hearing capacity of children with $\mathrm{CP}$, which in turn will affect their speech development, because language development in these children actually depends more on hearing ability than the severity of cleft or surgical repair.

\section{PSYCHO-SOCIAL ASPECTS}

Children with clefts undergo substantial surgical and orthodontic treatment over mostly the first 18 years of life, and may even pose a lifelong morbidity. Other than imposing a substantial economic burden, these may clearly impact their psycho-social development. Achievement in school among children with congenital clefts appears to be lower than normal children. The reasons are not well understood but appear to be related to hearing, speech, social, emotional and specific diagnostic factors. In social settings, studies have shown that children with clefts suffer in peer relations, are shy, and socially withdrawn. They also tend to marry later and less frequently than normal siblings, participate in fewer social activities, and depend more on family for support. However psycho-social distress and tensiontype headache level between adults with repaired CLP and normal adults were shown to be similar."

\section{CLASSIFICATION}

Cleft of the lips can be broadly categorized into complete and incomplete, either unilateral or bilateral. Incomplete $\mathrm{CL}$ is characterized by a varying degree of vertical lip separation, ranging from a slight mucosal covering, to defect in the bulk of the orbicularis muscle, with no involvement of the nasal sill. Complete CL involves defect of the full-thickness of the lip and alveolus, which is often accompanied by a secondary palatal cleft (Figure 1). ' CL may present with or without a CP. Palate clefts are either complete or incomplete, and can as well be unilateral or bilateral. A complete $\mathrm{CP}$ involves both primary and secondary palate, whereas incomplete $\mathrm{CP}$ affects only the secondary palate. $\mathrm{CP}$ is unilateral complete when palatal process of the maxilla is still fused with the nasal septum on one side, and bilateral complete if there is no attachment of palatal process to the nasal septum on either side (Figure 2$)^{6}$

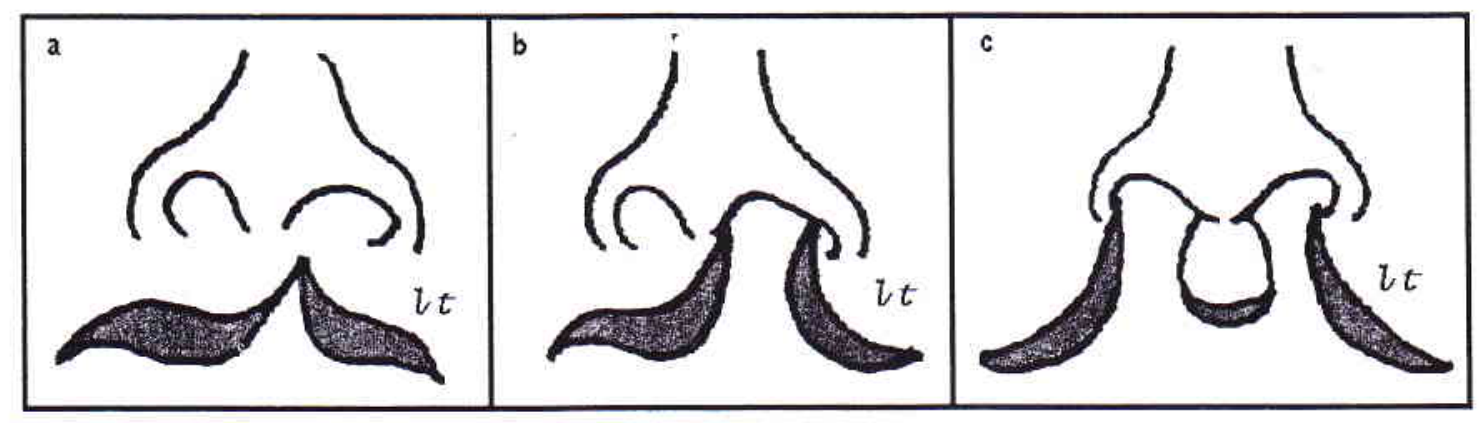

Figure 1. Types of Cleft Lips

(a) Unilateral incomplete, (b) Unilateral complete, (c) Bilateral complete 


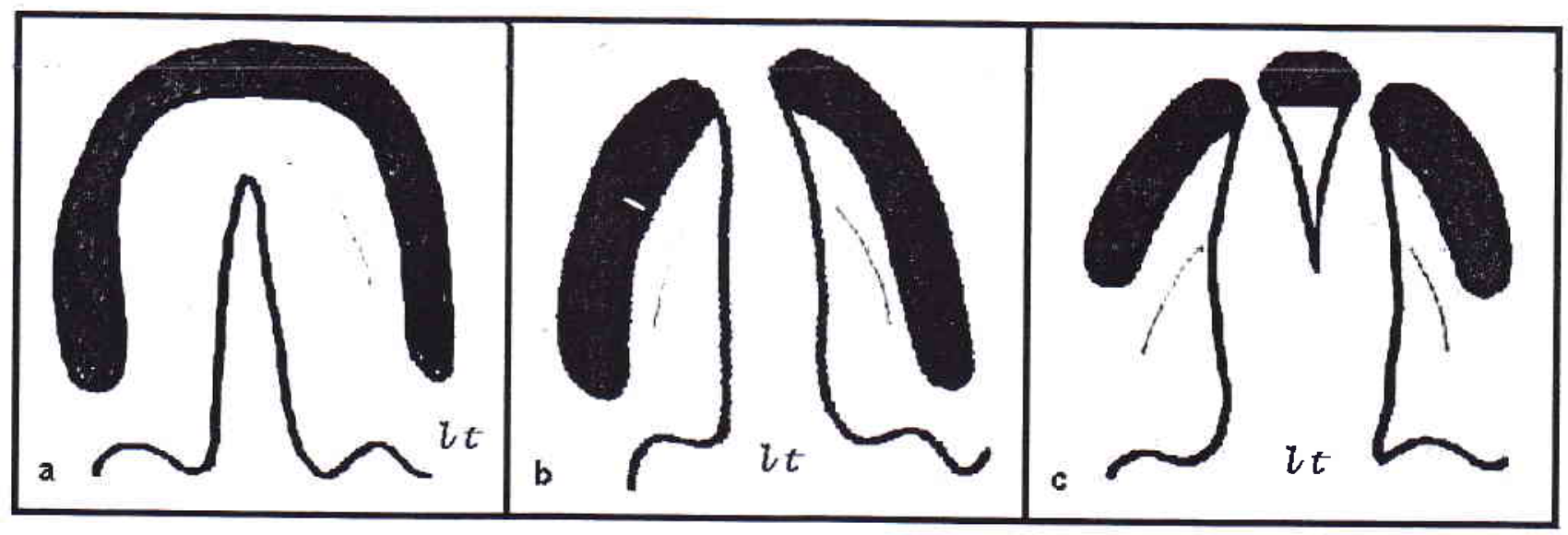

Figure 2. Types of Cleft Palate

(a) Incomplete, (b) Unilateral complete, (c) Bilateral complete

Documenting specific cleft diagnoses in writing has always been challenging for in most cases clefts are not as simple as 'lip' and 'palate' or unilateral/bilateral. To record for example a case of "right partial cleft lip associated with a complete soft palate cleft partially extending into the right hard palate" takes 18 words and considered ineffective, therefore efforts of a concise coding of the clefts has challenged several. Two documentation systems have been made: (1) using letters or numbers to define the cleft regions or the degree of clefting, and (2) using visual symbols.

With the much development these classifications had evolved through, still there is no single accepted universal classification being used until today. This results in a diverse inconsistent naming and grouping of clefts when practitioners establish a diagnosis. We appraise in brief the development of cleft classifications since the 1920s, to provide an insight of review for decision makers in the Cleft Centers. In the past, several experts had tried to develop several numerical and alphabetical grouping of clefts. These classifications however, are no longer in use. They were either insufficient in incorporating all kinds of clefts, or were too complex to use.

In 1963, Pfeifer developed a schematic outline of cleft areas in the form of a vertical block of three rectangular pairs referring to the right and left lip, alveolus, and hard palate, on top of a triangle that represents soft palate (Figure 3). He showed complete clefts by blackening the areas and partial clefts by cross lining the areas. Submucous clefts could not be recorded. The greatest disadvantage of such symbol is that it cannot be written in words hence difficult for modem computer data processing and communication. ${ }^{4}$

In 1971, Desmond Kernahan published the striped "Y" system (Figure 4). The right and left limbs of the "Y" are divided into three sections: the anterior portion is the lip ( 1 and 4), the middle is alveolus ( 2 and 5), and the posterior is the area of the hard palate from the alveolus back to the incisive foramen ( 3 and 6). Posterior to the incisive foramen, the hard ( 7 and 8 ) and soft (9) palate are also divided into three segments. He assigned number to each subdivision to facilitate computerized data processing. The "Y" itself is reproducible by a rubber stamp. Clefts are indicated by filling in the respective segments. Horizontal lines indicate submucous clefts where a true cleft is not present. ${ }^{4}$

Shortly after, Elsahy proposed a modifed striped "Y" (Figure 5). He added two triangles, two circles and two arrows to improve the striped $Y$. This modification caused the numbers in the squares to shift. Arrows help indicate direction of deflection in hard palate clefts. By addition of the two circles representing premaxilla and pharynx, premaxilla protrusion and velopharyngeal competence can be incorporated using this modified "Y". 4

In 1976 Millard then added inverted triangular tips on top of the modified "Y" to represent nasal deformity of the nostril arch (Figure 6). He, however, discount the upper and lower circles and the two arrows of Elsahy's. 
Like the two previous "Y"s, filled areas indicate a cleft, horizontal lined areas indicate submucosal muscle and bony clefts, and the inverted triangles will be marked with horizontal lines of density proportionate to the severity of nasal arch distortion. ${ }^{4}$

\section{Total}
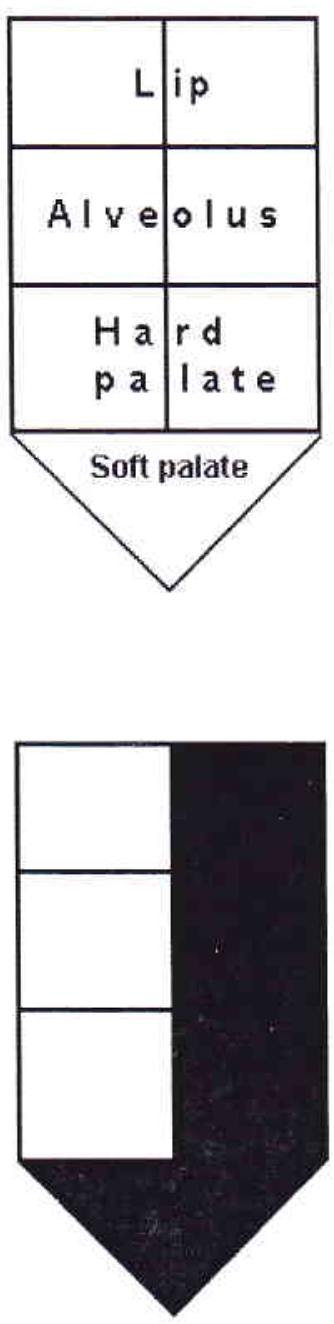

c

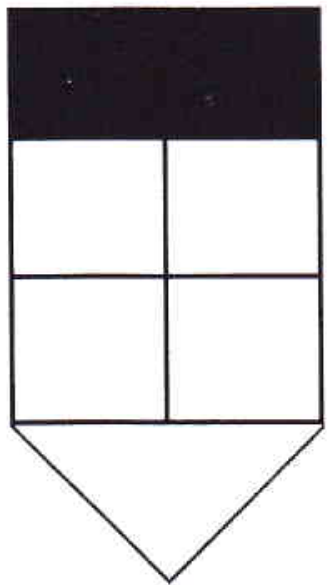

a

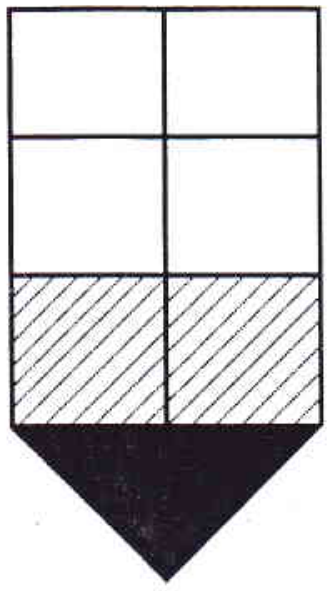

d

\section{Partial}

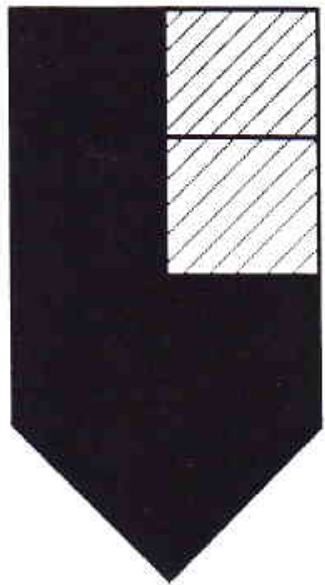

b

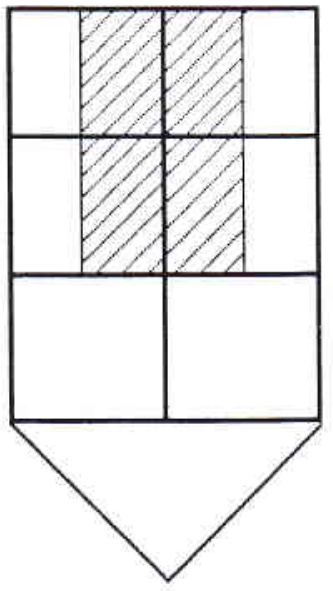

e

Adapted from Schuchardt K. Treatment of Patients with Clefts of Lip, Alveolus, and Palate Stuttgard, Thieme: Verlag; 1966

Figure 3. Pfeifer is Clefi lllustrations

(a) Complete biluteral clefi lip. (b) Complete right cleft lip and palate, partial left clefi lip involving the alveolus, (c) Complete cleft lip and palate, bilateral cleft of soft palate. (d) Bilateral cleft of soft palate, extending into partial cleft of bilateral hard palate.

(e) Incomplete medial clefi of lip involving the alveolus. 


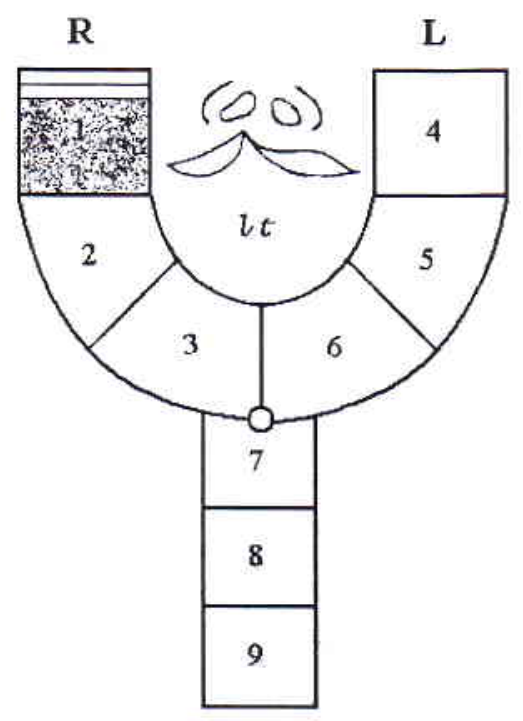

a

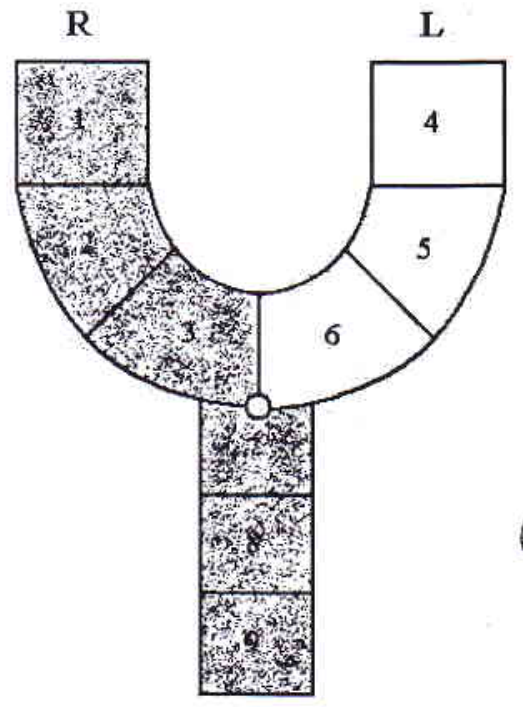

d

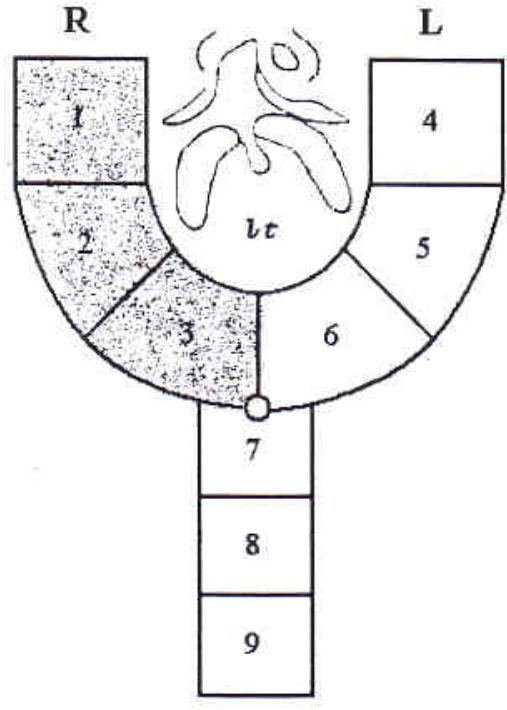

b

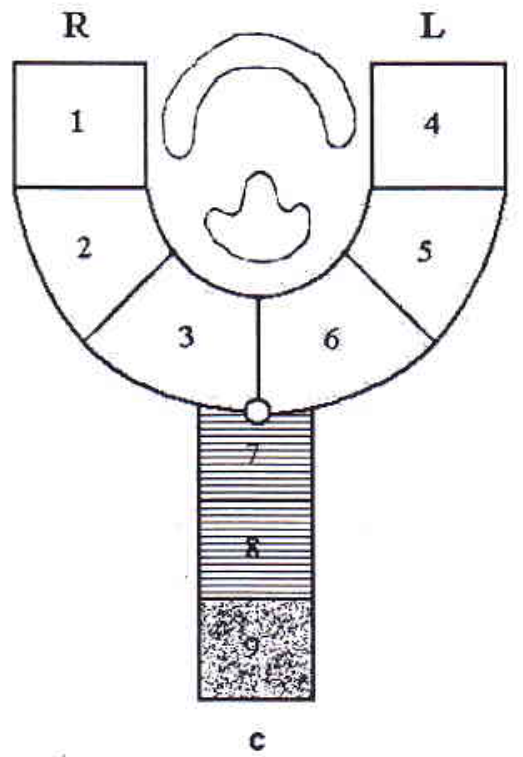

L

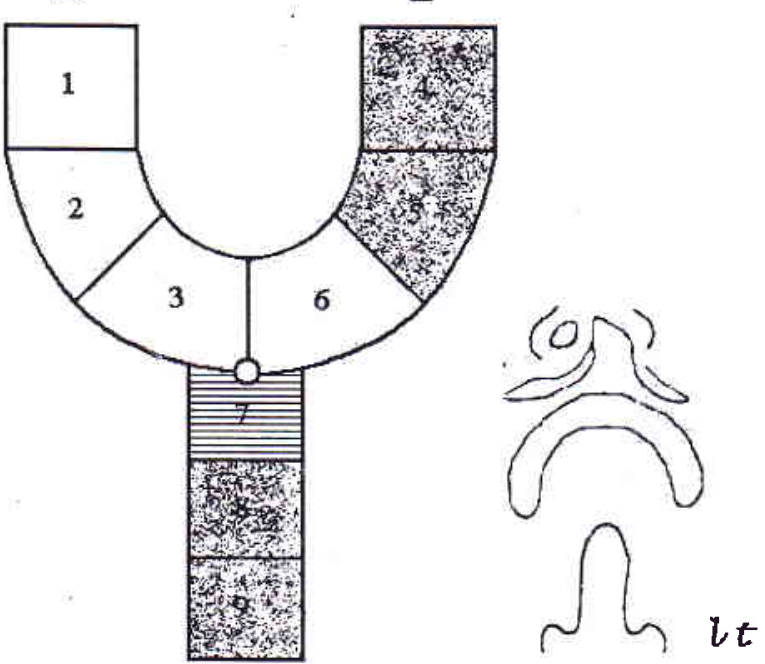

e

Figure 4. Kernahan's Striped " $Y$ "

(a) Incomplete right cleft lip, (b) Complete right cleft lip extending to alveolus, (c) Cleft of soft palate extending partially to hard palate, (d) Complete right cleft lip and palate, (e) Complete left cleft lip and cleft of the soft palate extending to hard palate 


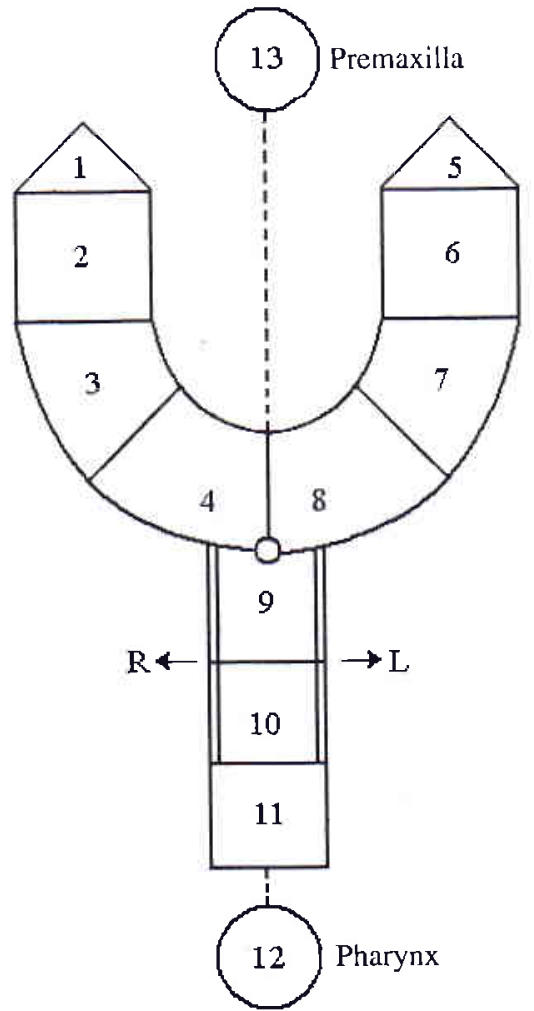

Adapted from Millard DR. Cleft craft: the evolution of its surgery. Boston: Little Brown \& Co; 1976

Figure 5. Elsahy's Modified "Y"

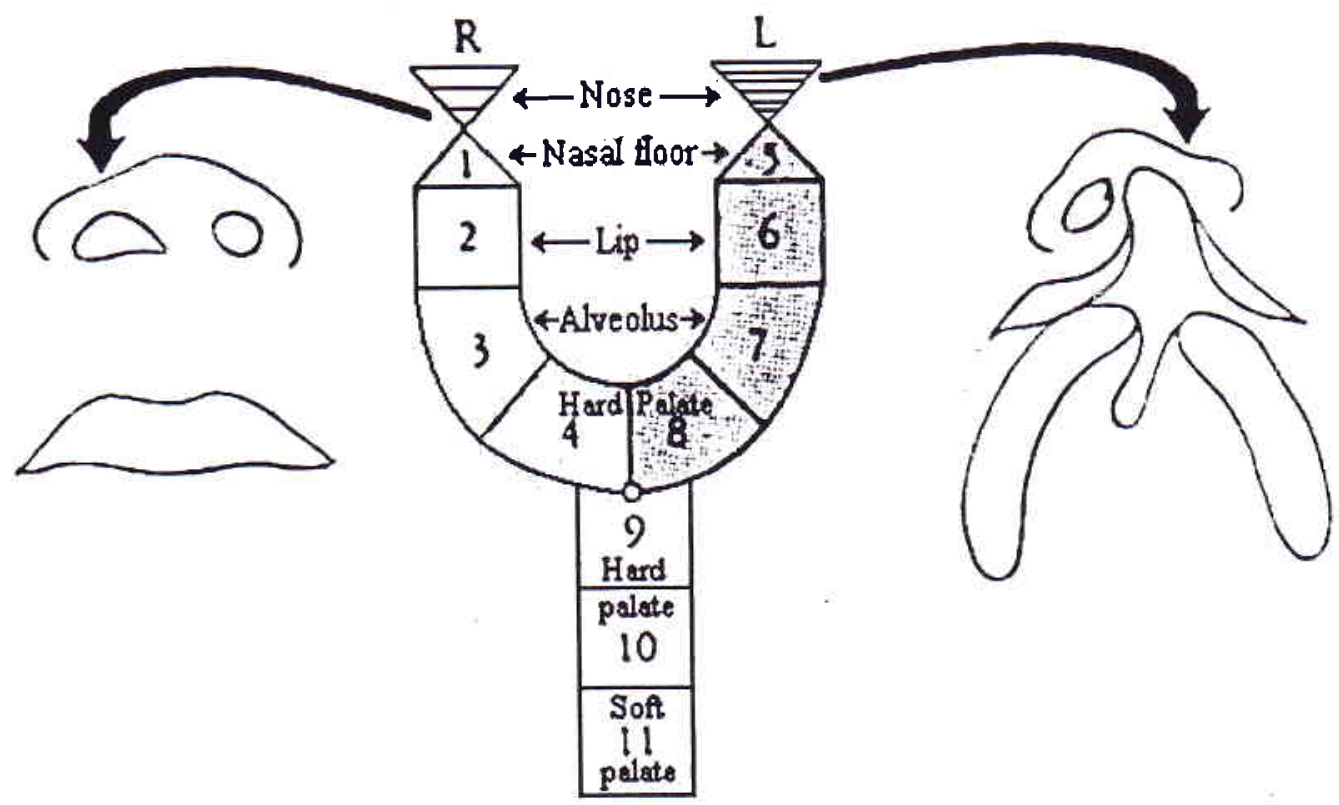

Adapted from Millard DR. Cleft craft: the evolution of its surgery. Boston: Little Brown \& Co; 1976

Figure 6. Millard's Inverted Triangles on the " $Y$ " 
In 1989, Kriens ${ }^{12}$ suggested an easy alphabetical documentation of clefts which divide the mouth into six areas: Lip (right), Alveolus (right), Hard palate (right), Soft palate, Hard palate (left), Alveolus (left), Lip (left); famous for its acronym LAHSHAL. When a defect presents, a letter is marked according to its corresponding area. Full defect is marked with capital letter, partial defect with small letter, and microforms with small letter in parenthesis (Figure 7). Areas with no defect are marked with a dash.
In 1991, Friedman ${ }^{13}$ proposed a new symbolic representation, combining the work of Elshay and Millard, by assigning severity scores to the anatomic and functional deformities instead of shading the segments of the "Y" (Figure 8 and Table 1). He proved such system easier to use in computed data storage and retrieval for standardized medical recordkeeping, clinical research and epidemiologic survey. The weakness would be the subjective interpretation of 'mild', 'moderate' and 'severe' on assigning scores for the nose and velopharyngeal segments.
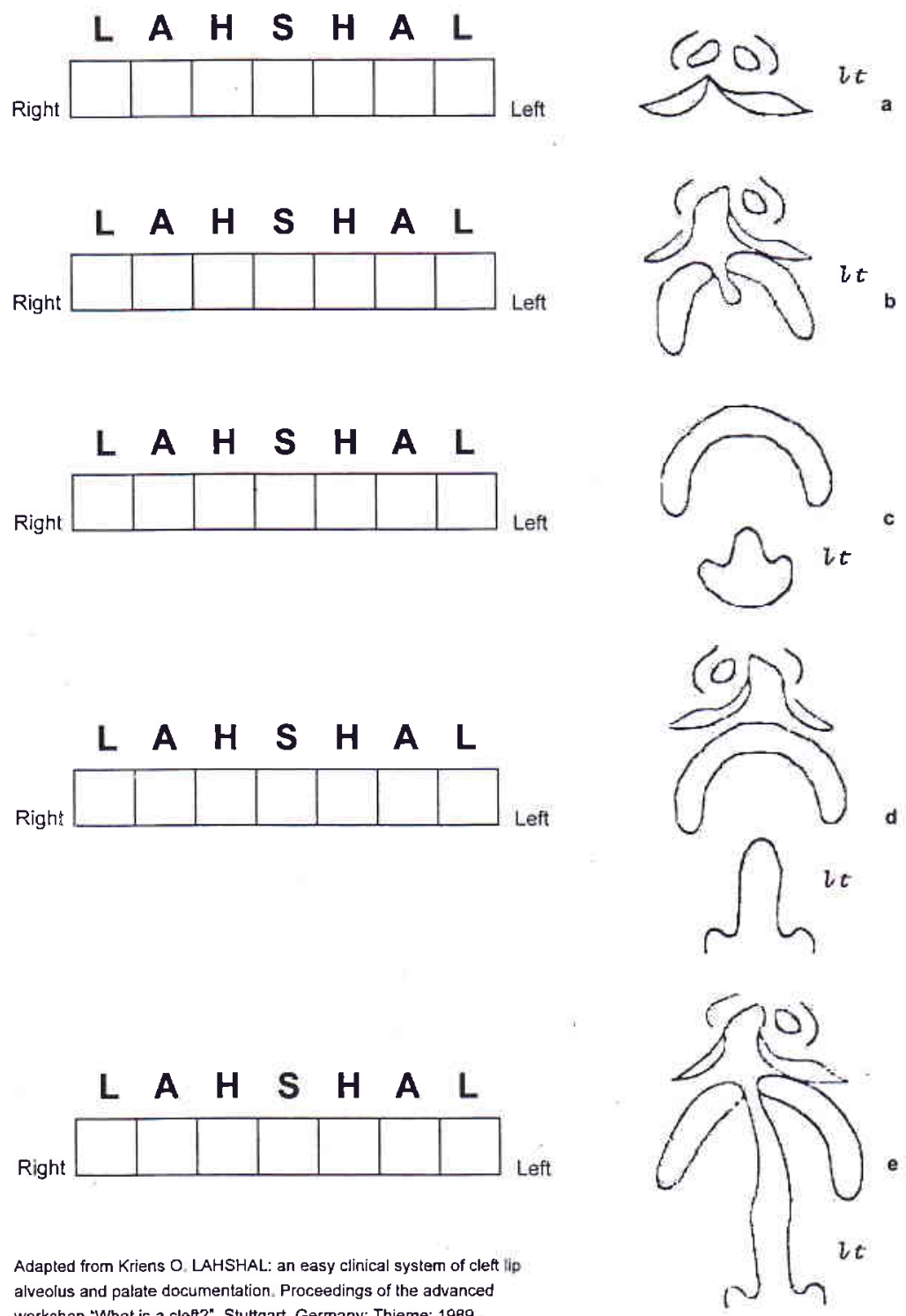

Adapled from Kriens O. LAHSHAL: an easy clinical system of cleft lip alveolus and palate documentation. Proceedings of the advanced workshop "What is a cleft?". Stultgart, Germany: Thieme; 1989

Figure 7. Kriens' LAHSHAL Clefts Documentation System

(a) Incomplete right cleft lip, (b) Complete right cleft lip extending to alveolus, (c) Cleft of soft palate extending partially to hard palate, (d) Complete right cleft lip and palate, (e) Complete left cleft lip and cleft of the sofi palate extending to hard palate 


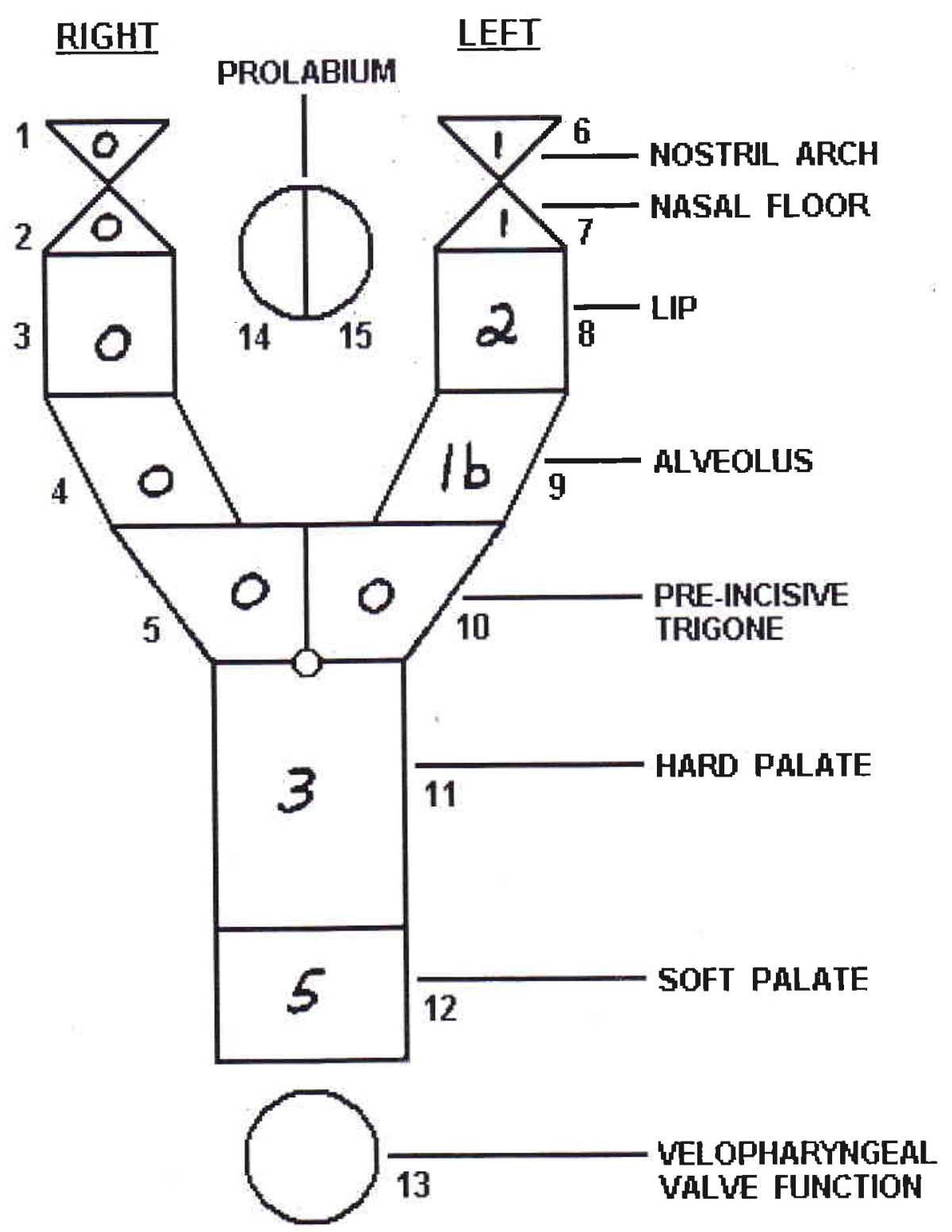

Adapted from Friedman HI, Sayetta RB, Coston GN, Hussey JR. Symbolic representation of cleft lip and palate. Cleft Palate Craniofac J. 1991;28(3):252-9.

Figure 8. Friedman's " $Y$ " Score 
Table 1. Coding Instructions for Friedman's "Y" Score

\section{CODING INSTRUCTIONS}

STEP 1 \#1, 6: Nostril Arch (including ala) $\# 2,7$ : Nasal Floor (including sill)

$$
\begin{aligned}
& \text { Record in appropriate boxes } \\
& 0=\text { no involvement } \\
& 1=\text { cleft microform } \\
& 2=\text { mild deformity } \\
& 3=\text { moderate deformity } \\
& 4=\text { severe deformity } \\
& \mathrm{x}=\text { not rated }
\end{aligned}
$$

\section{STEP 2 \#14, 15: Prolabium}

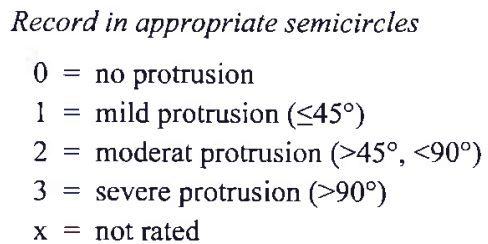

\section{STEP 3 \#3, 8: Upper Lip}

$$
\begin{aligned}
& \text { Record in appropriate boxes } \\
& 0=\text { no ivolvement } \\
& 1=\text { cleft microform }(\mathrm{u}, \mathrm{b})^{1} \\
& 2=1 / 3 \text { cleft lip } \\
& 3=2 / 3 \text { cleft lip } \\
& 4=\text { complete cleft lip } \\
& \mathrm{x}=\text { not rated }
\end{aligned}
$$

\section{STEP 4 \#4, 9: Alveolus}

Record in appropriate boxes:

$$
\begin{aligned}
& 0=\text { no involvement } \\
& 1=\text { cleft microform }(a, b)^{2} \\
& 2=\text { partial cleft } \\
& 3=\text { complete cleft }(a, b)^{3} \\
& x=\text { not rated }
\end{aligned}
$$

\section{SteP 5 \#5, 10: Pre-Incisive Trigone}

Record in appropriate boxes:

$$
\begin{aligned}
& 0=\text { no involvement } \\
& 1=\text { partial cleft } \\
& 2=\text { complete cleft } \\
& \mathrm{x}=\text { not rated }
\end{aligned}
$$

\section{STEP 6 \#11: Hard Palate}

Record in appropriate box

$$
\begin{aligned}
& 0=\text { no involvement } \\
& 1=\text { posterior } 1 / 3 \mathrm{cleft} \\
& 2=\text { posterior } 2 / 3 \mathrm{cleft} \\
& 3=\text { complete cleft } \\
& \mathrm{x}=\text { not rated }
\end{aligned}
$$

\section{STEP 7 \#12: Soft Palate, or Velum}

Record in appropriate box

$$
\begin{aligned}
& 0=\text { no involvment } \\
& 1=\text { cleft microform of uvula }(a, b, c)^{4} \\
& 2=\text { submucous cleft of velum }(a, b)^{5} \\
& 3=\text { posterior } 1 / 3 \text { of velum } \\
& 4=\text { posterior } 2 / 3 \text { of velum } \\
& 5=\text { complete cleft of velum } \\
& x=\text { not rated }
\end{aligned}
$$

\section{STEP 8 \#13: Velopharyngeal Valve Function}

Record in appropriate box

$$
\begin{aligned}
& 0=\text { no impairment } \\
& 1=\text { mild impairment } \\
& 2=\text { moderate impairment } \\
& 3=\text { severe impairment } \\
& \mathrm{x}=\text { not rated }
\end{aligned}
$$

\section{NOTES:}
1. Record as la = congenital scar in the usual cleft position (subcutaneous cleft)
$1 b={ }^{\prime}$ notch in the vermillion border
2. Record as $1 \mathrm{a}=$ submucous cleft
$\mathrm{Ib}=$ notch
3. Record as $3 \mathrm{a}=$ absence of maxillary arch collapse
$3 \mathrm{~b}=$ presence of maxillary arch collapse
4. Record as la = hypoplasia of musculous avulse
$1 b=$ septate uvula
lc = bivid uvula
5. Record as $2 \mathrm{a}=$ overt
$2 \mathrm{~b}=$ occult


Finally in 1993, Schwartz developed the RPL system by converting Kernahan's "Y" into a 3-digit numerical coding. The first digit of RPL represents the right " $Y$ " limb (No. 1, 2, 3), the second digit is "Y" base (No. 7,
8,9 ), and the third is the left limb (No. 4, 5, 6). Because each digit represents no more than three anatomical structures their value will not exceed 3 . The 63 possible clefts are each assigned to an RPL number (Table 2) ${ }^{14}$

Table 2. Schwartz's RPL System

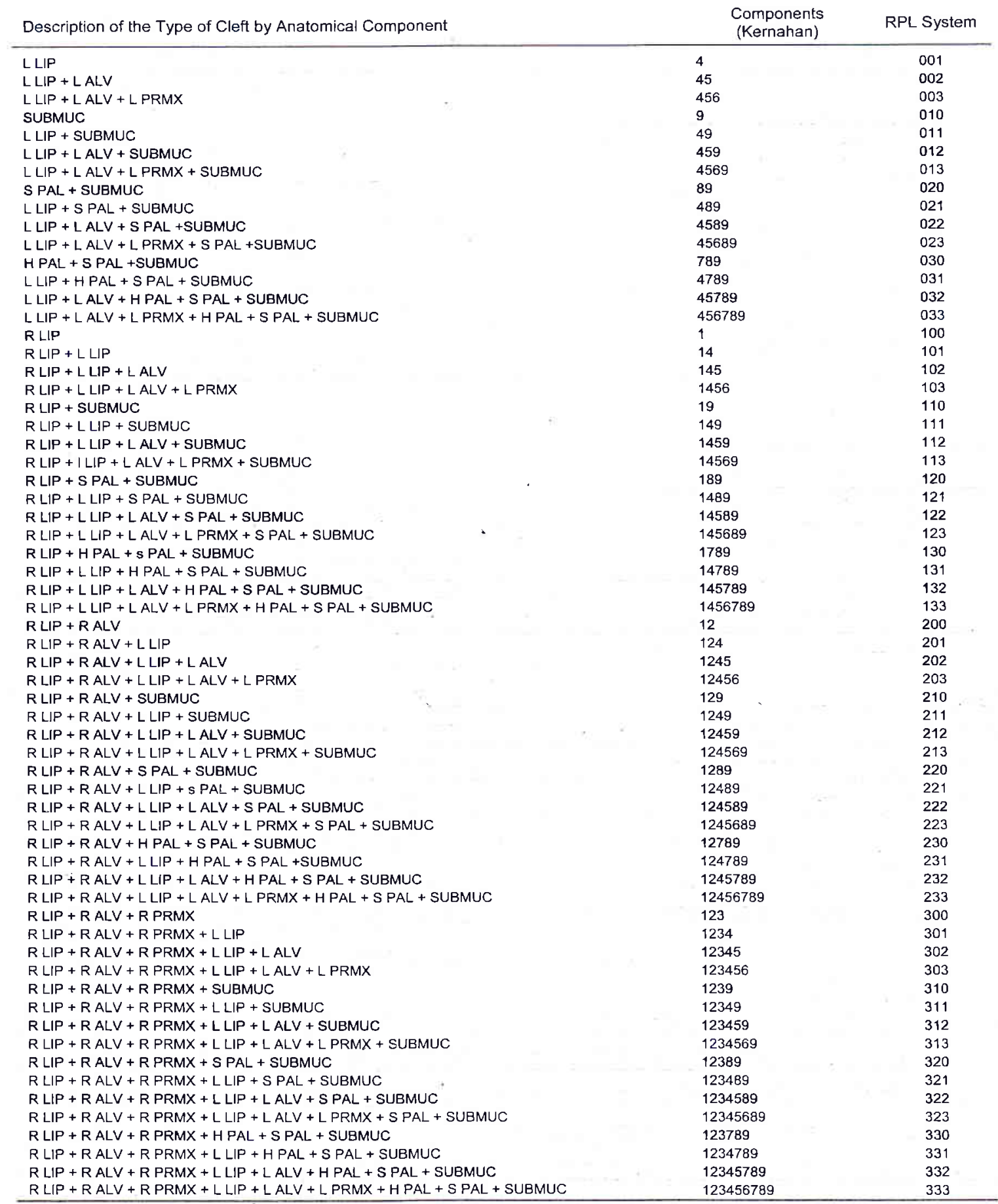

$A L V=$ alveolus, $P R M X=$ premaxilla, $H$ PAL $=$ hard palate,$S$ PAL $=$ soft palate, and $S U B M U C=$ submucous

Adapted from Schwartz S, Kapala JT, Rajchgot H, Roberts GL. Accurate and systematic numerical recording system for the identification of various types of lip and maxillary clefts (RPL system). Cleft Palate Craniofac J. 1993;30(3):330-2. 
$\mathrm{CL} / \mathrm{CP}$ may also occur as isolated (non-syndromic) or syndromic. Isolated is when cleft occurs alone with no other physical abnormalities found in the body, and no known teratogenic exposures. Isolated clefts, also known as nonsyndromic cleft, will only interfere in functional result that is related to the local effect of the cleft. Syndromic is when clefts occur together with other structure or organ malformation. It results from primary defects in morphogenesis. CL and CP can be associated to a lot of syndromes, to mention a few: $2 q$ Deletion, 4q Deletion, 4p, Apert, Catch22, Cleidocranial, Down, Marfan, Ectrodacytyly-ectodermal-dysplasia-clefting, Frontonasal dysplasia, Holoprosencephaly, Pierre Robin, Trisomy 18, Pseudotrisomy 13, TreacherCollins, Van der Woude, Velocardiofacial, Turner, and other less occurring syndromes. ${ }^{15}$ The most common syndrome associated to CLP is the van der Woude syndrome, characterized by unilateral or bilateral CL/ $\mathrm{CP}$ with distinctive medial lower lip pits and possible bifid uvula. The most common syndrome of cleft palate is the velocardiofacial syndrome distinguished by palatal abnormalities, cardiac defects, distinctive facial characteristics, hypernasal speech, hypotonia, developmental delay, and learning disabilities. ${ }^{16}$

There is no universally accepted classification of CLP. As new cases emerge and variant of cleft complexities discovered, prior classifications are somehow in some ways always inadequate. Over the years up to today, many authors are still trying to formulate the "perfect" classification to include as much detail of morphology, embryology, severity, and the most complete possible description of clefts in hope for a thorough accurate documentation which can be collectively used. Precise description of clefts is important for surgeons to take into account the complexity of the surgical correction to be done. Among the reviewed methods of classification, authors favor the LAHSHAL documentation system for use in daily clinical settings. This system is fairly simple, uncomplicated to remember, while adequately incorporates most type of clefts including microforms. When writing medical records, the LAHSHAL boxes can simply be reproduced using rubber stamp, and when desired, a straight-forward alphabetical data input for computer documentation is also possible.

\section{SURGICAL CORRECTION AND TREATMENT}

Children with $\mathrm{CL} / \mathrm{CP}$ will require long years of continuous medical care and treatment. To work hand in hand and manage these children, a team approach is essential. The team typically includes a plastic surgeon and an oromaxillofacial surgeon who are responsible for the most part of surgical reconstruction; an otolaryngologist, audiologist and speech pathologist to assist in hearing, verbal and language skills; a pediatrician who regularly monitors general health status of the child and gives early referral when necessary; a pediatric dentist, orthodontist and prosthodontist who take care of the non-surgical treatment of dentition and jaws positioning; a psychologist to assist the child on psychological and social welfare; nursing officers who are responsible for the daily health care of the child as well as advising parents on feeding difficulty; finally a social worker who helps handle matters regarding treatment and hospitalization, outside the scope of medical interventions.

There is no universally accepted surgical treatment regimen for CL/CP. Both the timing of the surgery and the preferred repair techniques vary among centers. A study in Europe alone revealed 184 different protocols. ${ }^{17}$ But surgery for repair of the CL/CP is almost always performed if no other complications are present. The anatomical objectives of $\mathrm{CL}$ repair are to attain: (i) continuity of the muscle, (ii) symmetry of the floor and sill of the nostril, (iii) natural appearance of the Cupid's bow, and (iv) minimal scarring. While the objectives of $\mathrm{CP}$ repair are to: (i) construct a symmetrical nose with open, functional nostrils, (ii) create alveolar integrity of the cleft area, (iii) minimize growth retardation of the maxilla, and (iv) create an intact palate that will support normal speech development. Other than general improvements in look and anatomical positions, repair of the cleft palate (CP) improve ventilatory function of the Eustachian tube, thus lower the chances of otitis media emergence, and help patients maintain good hearing.

\section{POST-SURGICAL RESULTS AND PROGNOSIS}

Prognosis for infants with isolated CL and isolated CP are excellent, provided that no infection nor trauma develops. ${ }^{18}$ However in infants with syndromic clefts, prognosis is more varied and complex depending on the syndrome involved. ${ }^{19}$ There are ways to measure the success of a cleft repair surgery such as by Mortier's or Ortiz-Posadas' numerical systems. They provide precise analytical comparison of postsurgical results, depending on the severity of clefts and the complexity 
of surgery done. Using these systems also allow a long-term tracking of postoperative appearance during follow ups. ${ }^{20,21}$

Following surgical repair of the CLP, long-term oral health management of children with CLP is crucial because the prevalence of dental caries, enamel hypoplasias, enamel erosions and gingivitis is greater in these children as compared to their peers. ${ }^{22}$ A variety of reasons for this high caries prevalence has been postulated, one may due to the irregular structure of the teeth, other proposes enamel defects as the culprit. ${ }^{23}$ While the precise etiology remains unclear, fluoride uptake will benefit these children in decreasing caries experience, may it be in form of fluoride supplements or plain use of fluoridated water. ${ }^{24}$ Prevention of dental diseases is important as such dental caries will sequel in extraction of teeth and may eventually hinder the development of good speech. Therefore it is advised that children with clefts should receive regular orthodontic checkups, diet advice, oral hygiene advice, and proper fluoride supplementation.

\section{DISCUSSION}

Adequate nutrition is essential for normal overall growth in infants, and especially worth a close monitoring for, in infants with congenital defects. $\mathrm{CL}$ or $\mathrm{CP}$, in particular, may present syndromically with other defects. One of the frequent infections that happens in children with clefts are the upper respiratory tract infection (URTI) and otitis media. As mentioned, patients with cleft palate have abnormal functioning of the muscles that control the opening and closing of Eustachian tube. This disturbs ventilation of the tube making it easier for ingested material -in infants' case, milk- to enter the tube, stays there and initiate an infection. So caretakers should be familiar with the signs of infections and refer early when the child is suspected to suffer from infection.

Psychosocial problems due to cleft defects may appear as early as infancy. Studies show that parents found it harder to accept a child with a facial defect than to accept a normal child. Feelings of isolation, guilt, anxiety, and denial faced by most parents of infants with birth defects hinder a good infant-maternal interaction. Mothers of CLP and craniofacially deformed infants tend to engage in less frequent smiling, vocalizing, imitative behaviors and game playing with their infants than mothers of normal infants.
Social stigma affiliated with clefts may lead to many other psychosocial disadvantages including staring, remarks, curiosity, questioning, pity, rejection, ridicule, whispering, nicknames, and discrimination from early on in life. Later in life, social rejection may extend to interfere their attempts to obtain jobs, finding life partners, or even make friends. This reflects the recognition that people's reaction to facial defects may be more damaging psychologically than the deformity itself. The parents think their clefted child is somewhat different than normal kids; it is a logical defense when they protect the child from outsiders whom they think may misdemeanor. Toward the child itself, parents tend to be more tolerant about misbehavior and conduct problems. This, although done with good intention, may in turn be harmful for attitude and conduct development of a child with cleft. Family consultation with psychologists may be helpful to tackle psychosocial aspects when caring for children with clefts.

Early surgical intervention is important in children with clefts. They improve functionality and aesthetics of patient, therefore aiding physical and mental growth for the children. The optimum timing of the multistaged surgeries has been, and still is, much of a debate. Centers around the world have different protocols. When present with both cleft lip and cleft palate, however, surgery of lips are always done first. Some have done it as early as 2 months old. Cleft palate repair are mostly done around 1 to 2 years old. This is crucial as it will be the determinant factor of speech acquisition that will come around that age. Six months after the palatoplasty, the child will need to start sessions with a speech therapist to aid in speaking and phonation.

\section{CONCLUSION}

Cleft lip with or without cleft palate as one of the most occuring human birth defects, which carry notable lifelong economic burden and morbidity, is a result of multiple genetic and environmental factors with complex etiology. Up to date, sufficient preconceptual intake of folic acid, not smoking and not consuming alcohol have been proven to reduce the risk for $\mathrm{CL} / \mathrm{CP}$. However not all contributory environmental factors and definite genes of $\mathrm{CL} / \mathrm{CP}$ are known yet. A vast number of studies have reached investigations up to molecular level to identify these candidate genes, mostly using genetically modified mice for ethical and practicality purpose, to understand the gene pathways and the nature 
of signaling molecules in a tissue-specific manner and the role they play for $\mathrm{CL} / \mathrm{CP}^{25}$

To incorporate the many presenting forms of clefts, practitioners had been attempting to formulate a single method of documentation which can be applied in clinical settings universally. This challenge has not been accomplished, for reasons that prior classifications are either inadequate or too complex. There is not yet a uniformly accepted cleft classification being used in daily practice, resulting in many variation and inconsistency between cleft centers in naming clefts.

Endless medical interventions for corrections following corrections on babies with cleft lip and/or cleft palate carry an equally heavy physical, mental, to material burden for the patient and their family. Team-approach is essential to aid them from all aspects. Surgical intervention remains as the first choice of treatment to correct the primary defect in patients with clefts.

\section{REFERENCES}

1. Han H, Kang N, Patel PK. Craniofacial, unilateral celft repair. Available at: http://www.emedicine.com/plastic/ topic 170.htm. 2002;Last updated: 14 Feb 2002. Cited on: 11 Feb 2006.

2. Croen LA, Shaw GM, Wasserman CR, Tolarova MM. Racial and ethnic variations in the prevalence of orofacial clefts in California, 1983-1992. Am J Med Genet. 1998;79(1):42-7.

3. CDC. Improved national prevalence estimates for 18 selected major birth defects -- United States, 1999-2001. MMWR. 2006;54(51\&52):1301-5.

4. Millard DR. Cleft craft: the evolution of its surgery. Boston: Little Brown \& Co; 1976.

5. Curtis EJ, Fraser FC, Warburton D. Congenital cleft lip and palate. Am J Dis Child. 1961;102:853-7.

6. Steward MG. Introduction to cleft lip and palate. Available online: http://www.bcm.edu/oto/grand/6191.html. 199l; Last updated: 23 Jan 2006. Cited on: 11 Feb 2006.

7. Wyszynski DF, Mitchell LE. Report of the newly formed International Consortium for Oral Clefts Genetics. Cleft Palate Craniofac J. 1999;36(2):174-8.

8. Livingstone VH, Willis CE, Abdel-Wareth LO, Thiessen P, Lockitch G. Neonatal hypernatremic dehydration associated with breast-feeding malnutrition: a retrospective survey. CMAJ. 2000;162(5):647-52.

9. Jocelyn LJ, Penko MA, Rode HL. Cognition, communication, and hearing in young children with cleft lip and palate and in control children: a longitudinal study. Pediatrics. 1996;97(4):529-34.
10. Shaw R, Richardson D, McMahon S. Conservative management of otitis media in cleft palate. J Craniomaxillofac Surg. 2003;31(5):316-20.

11. Marcusson A, List T, Paulin G, Dworkin S. Temporomandibular disorders in adults with repaired cleft lip and palate: a comparison with controls. Eur J Orthod. 2001;23(2):193-204.

12. Kriens O. LAHSHAL: an easy clinical system of cleft lip alveolus and palate documentation. Proceedings of the advanced workshop "What is a cleft?". Stuttgart, Germany: Thieme; 1989.

13. Friedman HI, Sayetta RB, Coston GN, Hussey JR. Symbolic representation of cleft lip and palate. Cleft Palate Craniofac J. 1991;28(3):252-9.

14. Schwartz S, Kapala JT, Rajchgot H, Roberts GL. Accurate and systematic numerical recording system for the identification of various types of lip and maxillary clefts (RPL system). Cleft Palate Craniofac J. 1993;30(3):330-2.

15. Milerad J, Larson $\mathrm{O}, \mathrm{PhD} \mathrm{D}$, Hagberg $\mathrm{C}$, Ideberg $\mathrm{M}$. Associated malformations in infants with cleft lip and palate: a prospective, population-based study. Pediatrics. 1997;100(2 Pt 1):180-6.

16. Cleft lip and palate. Available at: http://craniofacial. seattlechildrens.org/conditions. Seattle, Washington: 1995 2006; Cited on: 23 Feb 2006.

17. Shaw WC, Semb G, Nelson P, Brattstrom V, Molsted K, Prahl-Andersen B, et al. The Eurocleft project 1996-2000: overview. J Craniomaxillofac Surg. 2001;29(3):131-40.

18. Wong D, Hockenberry MJ, Wilson D, Winkelstein ML, Kline NE. Wong's nursing care of infants and children. 7th ed. St. Louis: Mosby; 2003.

19. Thigpen J, Kenner C. Assessment and management of the gastrointestinal system. Philadelphia: WB Saunders; 2003.

20. Mortier PB, Martinot VL, Anastassov Y, Kulik JF, Duhamel A, Pellerin PN. Evaluation of the results of cleft lip and palate surgical treatment: prelimiriary report. Cleft Palare Craniofac J. 1997;34(3):247-55.

21. Ortiz-Posadas MR, Vega-Alvarado L, Maya-Behar J. A new approach to classify cleft lip and palate. Cleft Palate Craniofac J. 2001;38(6):545-50.

22. Al-Wahadni A, Alhaija EA, Al-Omari MA. Oral disease status of a sample of Jordanian people ages 10 to 28 with cleft lip and palate. Cleft Palate Craniofac J. 2005;42(3):304-8.

23. Wong FW, King NM. The oral health of children with clefts--a review. Cleft Palate Craniofac J. 1998;35(3):24854.

24. Chapple JR, Nunn JH. The oral health of children with clefts of the lip, palate, or both. Cleft Palate Craniofac J. $2001 ; 38(5): 525-8$.

25. Da Lee R, Rhee GS, An SM, Kim SS, Kwack SJ, Seok JH, et al. Differential gene profiles in developing embryo and fetus after in utero exposure to ethanol. $\mathbf{J}$ Toxicol Environ Health A. 2004;67(23-24):2073-84. 
of signaling molecules in a tissue-specific manner and the role they play for $\mathrm{CL} / \mathrm{CP} .^{25}$

To incorporate the many presenting forms of clefts, practitioners had been attempting to formulate a single method of documentation which can be applied in clinical settings universally. This challenge has not been accomplished, for reasons that prior classifications are either inadequate or too complex. There is not yet a uniformly accepted cleft classification being used in daily practice, resulting in many variation and inconsistency between cleft centers in naming clefts.

Endless medical interventions for corrections following corrections on babies with cleft lip and/or cleft palate carry an equally heavy physical, mental, to material burden for the patient and their family. Team-approach is essential to aid them from all aspects. Surgical intervention remains as the first choice of treatment to correct the primary defect in patients with clefts.

\section{REFERENCES}

1. Han H, Kang N, Patel PK. Craniofacial, unilateral celft repair. Available at: http://www.emedicine.com/plastic/ topic 170.htm. 2002; Last updated: 14 Feb 2002. Cited on: 11 Feb 2006.

2. Croen LA, Shaw GM, Wasserman CR, Tolarova MM. Racial and ethnic variations in the prevalence of orofacial clefts in California, 1983-1992. Am J Med Genet. 1998;79(1):42-7.

3. CDC. Improved national prevalence estimates for 18 selected major birth defects -- United States, 1999-2001. MMWR. 2006;54(51\&52):1301-5.

4. Millard DR. Cleft craft: the evolution of its surgery. Boston: Little Brown \& Co; 1976.

5. Curtis EJ, Fraser FC, Warburton D. Congenital cleft lip and palate. Am J Dis Child. 1961;102:853-7.

6. Steward MG. Introduction to cleft lip and palate. Available online: http://www.bcm.edu/oto/grand/6191.html. 1991; Last updated: 23 Jan 2006. Cited on: 11 Feb 2006.

7. Wyszynski DF, Mitchell LE. Report of the newly formed International Consortium for Oral Clefts Genetics. Cleft Palate Craniofac J. 1999;36(2):174-8.

8. Livingstone VH, Willis CE, Abdel-Wareth LO, Thiessen P, Lockitch G. Neonatal hypernatremic dehydration associated with breast-feeding malnutrition: a retrospective survey. CMAJ. 2000;162(5):647-52.

9. Jocelyn LJ, Penko MA, Rode HL. Cognition, communication, and hearing in young children with cleft lip and palate and in control children: a longitudinal study. Pediatrics. 1996;97(4):529-34.
10. Shaw R, Richardson D, McMahon S. Conservative management of otitis media in cleft palate. J Craniomaxillofac Surg. 2003;31(5):316-20.

11. Marcusson A, List $T$, Paulin G, Dworkin S. Temporomandibular disorders in adults with repaired cleft lip and palate: a comparison with controls. Eur J Orthod. 2001;23(2):193-204.

12. Kriens O. LAHSHAL: an easy clinical system of cleft lip alveolus and palate documentation. Proceedings of the advanced workshop "What is a cleft?". Stuttgart, Germany: Thieme; 1989.

13. Friedman HI, Sayetta RB, Coston GN, Hussey JR. Symbolic representation of cleft lip and palate. Cleft Palate Craniofac J. 1991;28(3):252-9.

14. Schwartz S, Kapala JT, Rajchgot H, Roberts GL. Accurate and systematic numerical recording system for the identification of various types of lip and maxillary clefts (RPL system). Cleft Palate Craniofac J. 1993;30(3):330-2.

15. Milerad J, Larson $\mathrm{O}$, PhD D, Hagberg $\mathrm{C}$, Ideberg $\mathrm{M}$. Associated malformations in infants with cleft lip and palate: a prospective, population-based study. Pediatrics. 1997; 100(2 Pt 1):180-6.

16. Cleft lip and palate. Available at: http:/craniofacial. seattlechildrens.org/conditions. Seattle, Washington: 1995 2006,; Cited on: 23 Feb 2006.

17. Shaw WC, Semb G, Nelson P, Brattstrom V, Molsted K, Prahl-Andersen B, et al. The Eurocleft project 1996-2000: overview. J Craniomaxillofac Surg. 2001;29(3):131-40.

18. Wong D, Hockenberry MJ, Wilson D, Winkelstein ML, Kline NE. Wong's nursing care of infants and children. 7th ed. St. Louis: Mosby; 2003.

19. Thigpen J, Kenner C. Assessment and management of the gastrointestinal system. Philadelphia: WB Saunders; 2003.

20. Mortier PB, Martinot VL, Anastassov Y, Kulik JF, Duhamel A, Pellerin PN. Evaluation of the results of cleft lip and palate surgical treatment: preliminary report. Cleft Palate Craniofac J. 1997;34(3):247-55.

21. Ortiz-Posadas MR, Vega-Alvarado L, Maya-Behar J. A new approach to classify cleft lip and palate. Cleft Palate Craniofac J. 2001;38(6):545-50.

22. Al-Wahadni A, Alhaija EA, Al-Omari MA. Oral disease status of a sample of Jordanian people ages 10 to 28 with cleft lip and palate. Cleft Palate Craniofac J. 2005;42(3):304-8.

23. Wong FW, King NM. The oral health of children with clefts--a review. Cleft Palate Craniofac J. 1998;35(3):24854.

24. Chapple JR, Nunn JH. The oral health of children with clefts of the lip, palate, or both. Cleft Palate Craniofac J. 2001;38(5):525-8.

25. Da Lee R, Rhee GS, An SM, Kim SS, Kwack SJ, Seok JH, et al. Differential gene profiles in developing embryo and fetus after in utero exposure to ethanol. J Toxicol Environ Health A. 2004;67(23-24):2073-84. 